\title{
Budowa IV systemu sekrecji Legionella pneumophila i jego znaczenie w patogenezie
}

Bożena Kowalczyk, Agata Małek, Marta Palusińska-Szysz*

Katedra Genetyki i Mikrobiologii, Instytut Nauk Biologicznych, Wydział Biologii i Biotechnologii, Uniwersytet Marii Curie-Skłodowskiej, Lublin

Abstrakt

Bakterie Legionella pneumophila w środowisku naturalnym pasożytują wewnątrz komórek wybranych gatunków pierwotniaków, a po przedostaniu się do sztucznych systemów dystrybucji wody stają się ważnym czynnikiem etiologicznym zapalenia płuc u ludzi. Główną cechą determinującą patogenność tych bakterii jest zdolność do życia i replikacji w makrofagach płucnych, czyli w komórkach wyspecjalizowanych do fagocytozy, zabijania i trawienia mikroorganizmów. Warunkiem wstępnym rozwoju infekcji jest przełamanie mechanizmów bójczych makrofagów i utworzenie wakuoli replikacyjnej LCV (Legionella containing vacuole). Biogeneza wakuoli LCV jest możliwa dzięki sprawnemu funkcjonowaniu IV systemu sekrecji Dot/lcm, który jest wielobiałkowym, złożonym kompleksem umiejscowionym w wewnętrznej i zewnętrznej membranie osłony komórkowej bakterii. System Dot/lcm liczy 27 elementów, na które składają się m.in. kompleks rdzeniowo-transmembranowy, tworzący strukturalny szkielet całego systemu oraz kompleks białek sprzęgających. Geny kodujące komponenty systemu Dot/lcm są zorganizowane na dwóch regionach chromosomu bakteryjnego. System sekrecji Dot/lcm umożliwia L. pneumophila wprowadzenie do cytozolu komórki gospodarza ponad 300 białek efektorowych, których skoordynowane działanie powoduje utrzymanie integralności błony wakuoli replikacyjnej oraz pozwala na manipulowanie różnymi procesami komórki. Ważnym elementem strategii wewnątrzkomórkowego namnażania się L. pneumophila jest modulowanie transportu pęcherzykowego, interakcja z retikulum endoplazmatycznym oraz zakłócenie biosyntezy białek, procesów autofagii i apoptozy komórki gospodarza. Poznanie złożonych mechanizmów regulacji i funkcji białek efektorowych systemu Dot/lcm ma decydujące znaczenie w zapobieganiu i leczeniu choroby legionistów.

Słowa

kluczowe Legionella pneumophila • wewnątrzkomórkowe patogeny • system sekrecji Dot/lcm • wakuola replikacyjna • choroba legionistów

Otrzymano: 19.09.2020, Zaakceptowano: 24.02.2021

\section{Abstract}

Legionella pneumophila bacteria in the natural environment parasitize the cells of selected species of protozoa and, when present in artificial water distribution systems, they become an important etiological factor of pneumonia in humans. The main determinant of the pathogenicity of these bacteria is the capability to live and multiply in pulmonary macrophages, i.e. cells specialized in phagocytosis, killing, and digesting microorganisms. A prerequisite for the development of infection is the breakdown of the killing mechanisms of macrophages and the formation of the replication vacuole LCV (Legionella-containing vacuole). The biogenesis of the LCV vacuole is possible due to the efficient functioning of the IV secretion system Dot/lcm, which is a multi-protein complex located in the inner and outer membranes of the cell envelope. The Dot/lcm system consists of 27 components, including a core-transmembrane complex, which is the structural backbone of the entire system, and a complex of coupling proteins. Genes encoding the Dot/lcm system components are organized into two regions of the bacterial chromosome. The Dot/lcm secretion system enables L. pneumophila to introduce more than $\mathbf{3 0 0}$ effector proteins into the cytosol of the host cell, whose coordinated action maintains the integrity of the replication vacuole membrane and allows the manipulation of various cell processes. An important element of the intracellular multiplication strategy of $L$. pneumophila is the modulation of vesicular transport, interaction with the endoplasmic reticulum, and disruption of protein biosynthesis, autophagy, and apoptosis of the host cell. Understanding the complex mechanisms of regulation and function of the Dot/lcm effector proteins is critical in the prevention and treatment of Legionnaires' disease.

Keywords

Legionella pneumophila • intracellular pathogens • Dot/lcm secretion system • replication vacuole • Legionnaires' disease

Received: 19.09.2020, Accepted: 24.02.2021

*Corresponding author e-mail: marta.szysz@poczta.umcs.lublin.pl 


\section{Wprowadzenie}

Bakterie Legionella pneumophila to Gram-ujemne pałeczki, które w środowisku wodnym pasożytują w komórkach wolno żyjących pierwotniaków. Po przedostaniu się do systemów dystrybucji wody bakterie występują w sztucznych rezerwuarach, takich jak: sieci wodociągowokanalizacyjne, systemy klimatyzacyjne, wieże chłodnicze. Wdychanie skażonego wodno-powietrznego aerozolu wytwarzanego przez różne urządzenia może zakażać ludzi. W organizmie człowieka pałeczki Legionella zachowują się jak oportunistyczne patogeny zdolne do proliferacji wewnątrz monocytów i makrofagów alweolarnych oraz komórek nabłonkowych pęcherzyków płucnych, wywołując atypowe zapalenie płuc, zwane chorobą legionistów. Wyniki badań etiologii pneumonii wskazują, że pałeczki Legionella są odpowiedzialne za 2-16\% zachorowań, a w zachorowaniach o ciężkim przebiegu 14-37\% przypadków, w których śmiertelność przekracza 25\%. U chorych z supresją immunologiczną poziom śmiertelności jest jeszcze wyższy i może wynosić $60 \%$ [1, 2]. Najczęściej do infekcji dochodzi w środowisku zamieszkania, w czasie podróży oraz podczas pobytu w szpitalu. W Stanach Zjednoczonych liczba zgłoszonych przypadków choroby legionistów wzrosła z 2301 w 2005 r. do 7104 w 2018 r., co oznacza 300\% wzrost. W Europie liczba stwierdzonych przypadków tej choroby prawie się podwoiła (1,3/100 000 osób w 2014 r. do 2,3/100 000 osób w 2018 r.). Wzrost liczby przypadków może wynikać ze zmieniających się warunków środowiskowych, które sprzyjają namnażaniu się pałeczek Legionella, a także z rosnącej liczby osób podatnych na infekcję, takich jak osoby starsze i z obniżoną odpornością [3]. Zamknięcie budynków użyteczności publicznej związane z pandemią koronawirusa SARS-CoV-2 doprowadziło do długotrwałej stagnacji wody w instalacjach i stworzyło optymalne warunki do intensywnego namnażania się bakterii Legionella, czego następstwem jest znaczne zwiększenie liczby przypadków choroby legionistów [4].

W cyklu życiowym L. pneumophila występuje faza replikacyjna, wktórejbakterienamnażająsięwparazytosomach pierwotniaków lub w makrofagach człowieka oraz faza transmisyjna, w której bakterie są ruchliwe, gromadzą kwas $\beta$ hydroksymasłowy, wykazują zwiększoną oporność osmotyczną oraz są bardzo zakaźne. Przejście bakterii z fazy replikacyjnej, która się odbywa w zasobnej w składniki pokarmowe komórce gospodarza, do środowiska wodnego, które nie sprzyja rozwojowi bakterii, wymaga wytworzenia wielu unikalnych cech fenotypowych. Błona zewnętrzna $L$. pneumophila jest asymetryczną dwuwarstwą lipidową, której wewnętrzną część tworzą głównie fosfolipidy, a zewnętrzną lipopolisacharyd (LPS) [5]. Fosfolipidy L. pneumophila charakteryzują się dużą zawartością (30\%) fosfatydylocholiny - fosfolipidu charakterystycznego dla błon komórek eukariotycznych [6]. Część polisacharydowa LPS składa się z 10-75 podjednostek kwasu legionaminowego, który ze względu na obecność grup acetylowych i acetyloamidowych jest wysoce hydrofobowy [7]. Wysoka hydrofobowość warstwy powierzchniowej L. pneumophila zwiększa ich przeżywalność w aerozolu i ułatwia adhezję do membrany komórek gospodarza. Do lipidu A są przyłączone długołańcuchowe hydroksykwasy tłuszczowe, które zwiększają stabilność membrany zewnętrznej. Poza fosfolipidami i LPS-em błona zewnętrzna zawiera lipoproteiny oraz unikalny zestaw transmembranowych białek przybierających postać $\beta$-beczułek, których nie stwierdza się w obrębie błony wewnętrznej. Obie warstwy błony wewnętrznej składają się z fosfolipidów oraz białek integralnych i peryferyjnych. Przestrzeń peryplazmatyczna L. pneumophila zawiera stosunkowo cienką warstwę peptydoglikanu, w którego skład wchodzi kwas muraminowy, glukozamina, kwas glutaminowy, alanina i kwas mezodiaminopimelinowy w stosunku molowym 0,8:0,8:1,1:1,7:1 [8]. Bakterie L. pneumophila nie wytwarzają otoczek oraz nie syntetyzują zewnątrzkomórkowych polisacharydów, dlatego makrocząsteczki ściany komórkowej (białka, lipidy, LPS) odgrywają decydującą rolę na każdym etapie oddziaływania z komórką gospodarza. Bezpośredni kontakt między $L$. pneumophila a komórką docelową indukuje wydzielanie ponad 300 białek efektorowych za pomocą IV systemu sekrecji, które odgrywają podstawową rolę w biogenezie niszy replikacyjnej $[9,10]$. Bakterie $L$. pneumophila pobrane w wyniku spiralnej lub klasycznej fagocytozy przez komórkę makrofaga zostają zamknięte w wyspecjalizowanej wakuoli LCV (Legionella containing vacuole), która zapewnia schronienie przed mechanizmami obronnymi, umożliwia pobieranie składników odżywczych niezbędnych do wewnątrzkomórkowego namnażania się oraz ucieczkę z wyeksploatowanej komórki gospodarza [11].

\section{Budowa IV systemu sekrecji Dot/lcm L. pneumophila}

System sekrecji typu IV (T4SS) Dot/lcm (defective in organelle trafficking/intracellular multiplication) L. pneumophila tworzy złożony aparat białkowy, który spina wewnętrzną i zewnętrzną błonę ściany komórkowej. Model sekrecji i translokacji systemu Dot/lcm zakłada, że jeden z jego komponentów (prawdopodobnie IcmQ) buduje podobne do pilusów struktury na powierzchni bakterii, które tworzą kanały umożliwiające transport substratów poprzez membranę wakuoli zawierającej pałeczki Legionella [12, 13, 14, 15]. Geny kodujące komponenty aparatu Dot/lcm są zorganizowane na chromosomie L. pneumophila w dwa główne regiony, 
z których każdy ma w przybliżeniu 20 kpz długości (ryc. 1). Część z nich podlega wspólnej regulacji transkrypcyjnej. W regionie I znajduje się 7 genów: $\operatorname{dot} A, B, C, D$ oraz icmV, $W, X$. Kolejne 18 genów dot/icm znajduje się w II regionie, są to: icmS, $\operatorname{dotL} / / \mathrm{cmO}$, $\operatorname{dot} M / / \mathrm{cmP}$, dotN/IcmJ, dotF/lcmG, dotH/lcmK, dotU/IcmH, icmF, icmQ, icmR, dotO/icmB, dotE/ icmC, dotl/icmL, dotJ/icmM, dotK/icmN, dotP/icmD, icmT [13, 16, 17, 18]. Geny dot/icm są rozmieszczone w kilku klastrach

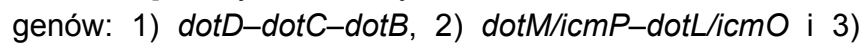
dotl/icmL-dotH/icmK-dotG/icmE [19]. Większość genów dot/ icm zawiera konserwatywną sekwencję TATACT, położoną w regionie 10 promotora, rozpoznawaną przez czynnik sigma RpoD [18].
Geny kodujące białka systemu Dot/lcm można podzielić na trzy kategorie fenotypowe:

- geny kontrolujące główny aparat transportowy,

- geny, których produkty kontrolują proces remodulacji membrany fagosomów,

- geny kodujące białka, które umożliwiają wydostanie się bakterii z komórki gospodarza po namnożeniu się oraz odpowiadają za tworzenie kanałów w plazmolemie.

System Dot/lcm składa się z 27 elementów, należą do nich: białko DotH/lcmK oraz lipoproteiny (DotC, DotD, DotK) błony zewnętrznej, białko peryplazmatyczne (IcmX), białka błony wewnętrznej (DotA, DotE, DotF (IcmG), DotG (IcmE), Dotl, DotJ, DotM, DotP, DotU, DotV, IcmF, IcmT i lcmV), ATP-
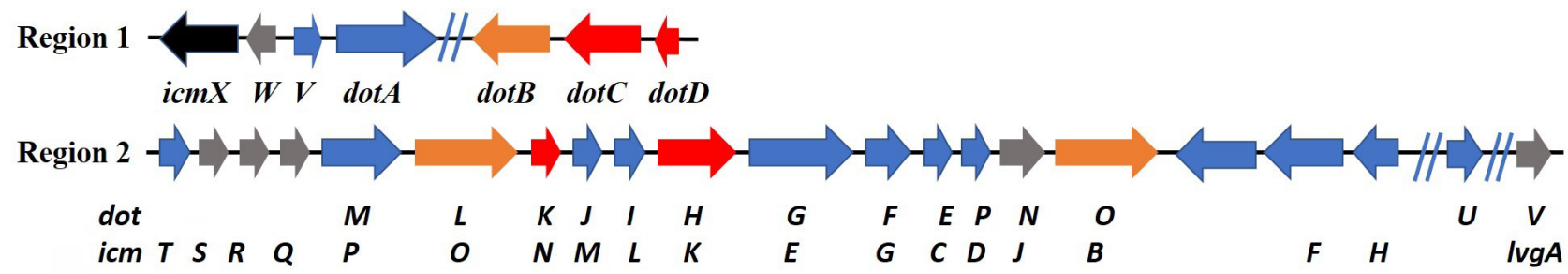

Rycina 1: Organizacja genów systemu sekrecji Dot/lcm na chromosomie L. pneumophila. Geny kodujące:

- białka błony zewnętrznej

- białka peryplazmatyczne

- ATPaza

- białka błony wewnętrznej

- białka cytoplazmatyczne

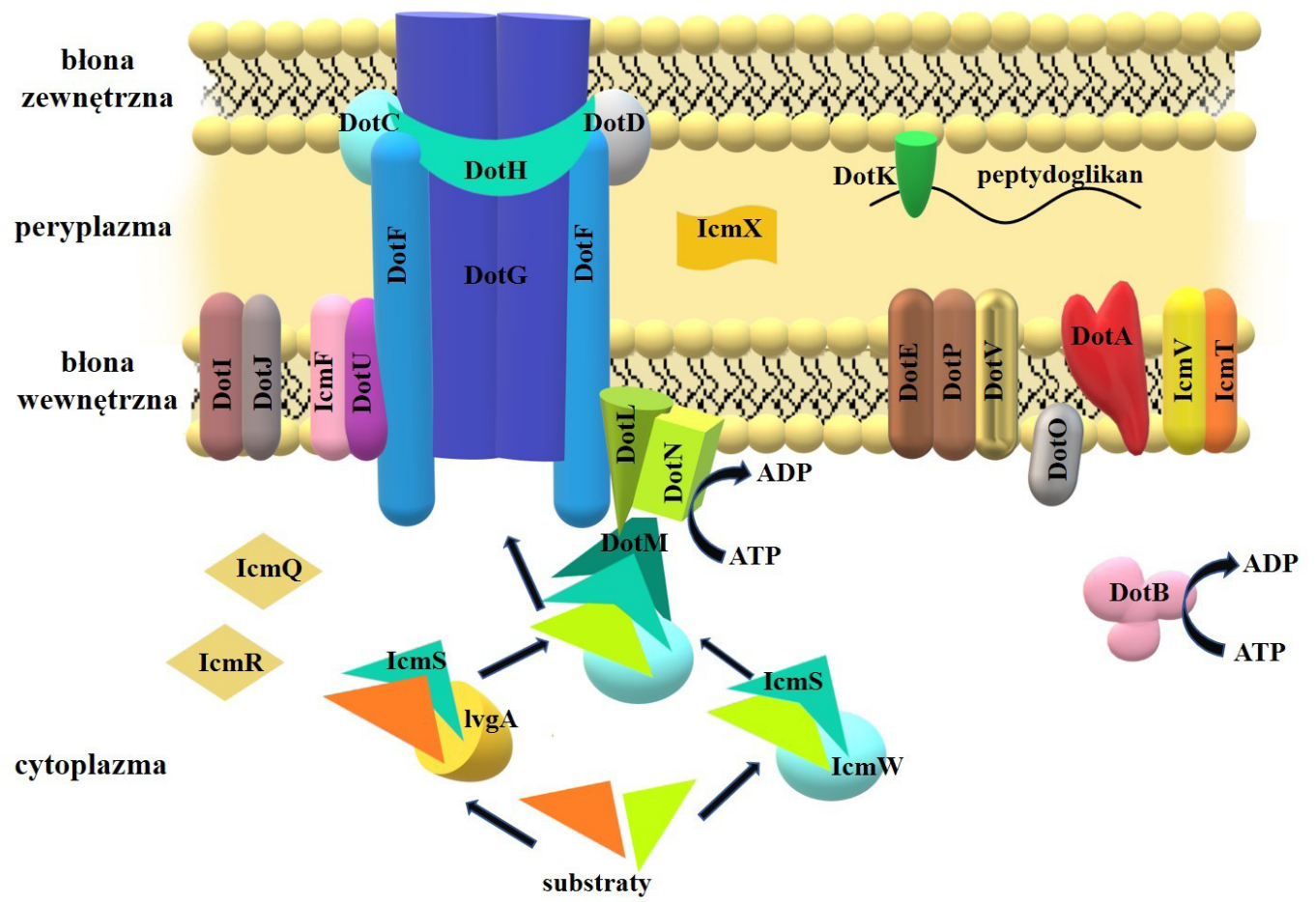

Rycina 2: Budowa białkowego aparatu sekrecji Dot/lcm L. pneumophila 
azy związane z błoną wewnętrzną (DotB, DotL, DotO) oraz rozpuszczalne białka cytoplazmatyczne (DotN, IcmQ, IcmR, IcmS, IcmW i LvgA) [19]. Białka te tworzą kilka kompleksów, m.in. kompleks rdzeniowo-transmembranowy (LCTM, Legionella core-transmembrane subcomplex) składający się z pięciu białek (DotC, DotD, DotF, DotG, DotH) oraz kompleks białek sprzęgających (LT4CP, Legionella type IV coupling protein subcomplex) złożony z sześciu białek (DotL, DotM, DotN, IcmS, IcmW, LvgA) [20] (ryc. 2).

\section{Składniki rdzeniowe}

Głównym podzespołem systemu T4SS $L$. pneumophila jest kompleks rdzeniowo-transbłonowy, tworzący strukturalny szkielet całego systemu. W jego skład wchodzi pięć białek: dwie lipoproteiny zewnątrzkomórkowe (DotC, DotD), dwa białka spinające membranę wewnętrzną (DotF $(\mathrm{IcmG})$, DotG (IcmE)) i jedno białko związane z membraną zewnętrzną DotH (IcmK) [21]. DotF oraz DotG są białkami błony wewnętrznej, których końce karboksylowe oddziałują z białkami błony zewnętrznej (DotC, DotD i DotH), dzięki czemu białka te przemieszczają się do membrany zewnętrznej [6]. Pory w błonie zewnętrznej tworzy białko DotH, którego prawidłowe umiejscowienie w strukturze membrany zależy od lipoprotein DotC i DotD [21, 22]. Kompleks rdzeniowo-transbłonowy $L$. pneumophila wykazuje funkcjonalną analogię do kompleksu Agrobacterium VirB7-10 [6].

Białko DotD jest zbudowane $z$ dwóch $\alpha$-helis flankowanych przez przeciwrównoległą trójniciową strukturę $\beta$-kartki na jednym końcu białka i mieszaną trójniciową strukturę $\beta$-kartki na drugim końcu cząsteczki białka. Domena białka DotD przypuszczalnie tworzy pierścień peryplazmatyczny, który jest częścią umiejscowionego w obrębie błony zewnętrznej kompleksu wyższego rzędu złożonego z białek DotC, DotD i DotH [21]. DotC sąsiaduje $z$ dwiema kopiami białka DotD (DotD1 i DotD2). Między powierzchnią DotD1 i DotD2 występują wiązania wodorowe oraz oddziaływania elektrostatyczne [23].

Białko DotF składa się z 269 aminokwasów i zawiera trzy domeny: N-końcową domenę cytoplazmatyczną złożoną z 50 aminokwasów, hydrofobową domenę transmembranową, zbudowaną z około 20 aminokwasów oraz C-końcową domenę peryplazmatyczną składającą się z około 200 aminokwasów [24]. Białku DotF przypisuje się dwie funkcje: pierwsza z nich zakłada obecność motywu podobnego do motywu występującego $\mathrm{w}$ grupie białek SNARE (soluble $\mathrm{N}$-ethylmaleimide-sensitive-factor-attachment protein receptor), który odpowiada za hamowanie procesu fuzji błon w komórce gospodarza w warunkach in vitro [15, 25]. Druga sugerowana funkcja białka DotF polega na jego bezpośrednim wiązaniu się z substratami transportowanymi podczas procesu eksportu przez kanał translokacyjny systemu T4SS [24].

Białkiem, które spina zewnętrzną oraz wewnętrzną błonę, tworząc centralny kanał w kompleksie rdzeniowym, jest białko DotG. Białko to prawdopodobnie odpowiada za transfer energii $z$ wewnętrznej błony do białka DotH tworzącego kanał w błonie zewnętrznej. Białko DotG wchodzi w interakcje z białkiem DotF na wczesnych etapach przenoszenia substratów za pośrednictwem systemu Dot/lcm, gdyż związanie substratu przez białko DotF może aktywować białko DotG. Po przeniesieniu substratu białko DotF może przekazywać sygnał zwrotny do błony wewnętrznej od strony cytoplazmy, który odpowiada za zmniejszenie aktywności białka DotG [6]. Jednak głównym zadaniem białka DotF jest stabilizowanie struktury kanału lub wpływanie na jego konformację [26].

Proces tworzenia się kompleksu rdzeniowotransmembranowego systemu Dot/lcm $L$. pneumophila składa się z trzech etapów. W pierwszym etapie dochodzi do wprowadzenia białka DotH do membrany zewnętrznej z udziałem białek DotC i DotD. Odpowiedni poziom ekspresji genów kodujących te trzy białka ma podstawowe znaczenie $w$ formowaniu się okrągłego kanału w kompleksie rdzeniowym systemu. W następnych etapach dochodzi do wbudowania białek DotF i DotG do membrany wewnętrznej oraz ich interakcji z pozostałymi elementami kompleksu w obrębie błony zewnętrznej (DotC, DotD, DotH). Powstaje spinający błonę wewnętrzną oraz zewnętrzną kompleks stanowiący rdzeń T4SS L. pneumophila [6].

\section{Kompleks białek sprzęgających}

Kompleks białek sprzęgających Legionella typu IV (LT4CP) jest umiejscowiony w membranie wewnętrznej. Składa się z białka sprzęgającego typu IV - DotL, białek aparatu Dot/ Icm - DotM, DotN, DotY, DotZ oraz cytoplazmatycznych białek adaptorowych typu IV - IcmS i IcmW, a także białka LvgA, któremu również przypisuje się funkcje adaptorowe $[27,28]$. Badania strukturalne wykazały, że rdzeń kompleksu jest utworzony $z$ heteropentameru DotLMNYZ, z którego wystaje elastyczny moduł IcmSW [27]. Centralną podjednostką kompleksu LT4CP jest białko DotL; należy do rodziny białek sprzęgających TraG, które klasyfikowane są jako ATPazy typu AAA+ pełniące funkcje wiązania substratów transportowanych przez kanał translokacyjny systemu sekrecji T4SS [28]. W przeciwieństwie do białek należących do rodziny TraG, białko DotL zawiera około 200 C-końcowych podjednostek stanowiących przedłużenia (CTE, C-terminal extension), które znacznie różnią się długością i sekwencją aminokwasową w porównaniu do innych białek sprzęgających [29]. Białko DotL zawiera cytoplazmatyczną 
C-końcową domenę $z$ konserwatywnym motywem Walkera A oraz wbudowaną w błonę wewnętrzną domenę N-końcową, która jest powiązana z białkami FtsK/SpollIE, należącymi do rodziny translokaz DNA [30]. Podjednostki CTE białka DotL oddziałują z heterodimerem IcmSW powstałym po dimeryzacji białek IcmS i IcmW, a także z białkiem DotN (IcmJ) i LvgA [29]. Ponadto białko DotL dzięki transbłonowym helisom oraz domenie ATPazy odpowiadającej za katalizowanie procesu hydrolizy ATP dostarczającego energię bezpośrednio do translokacji substratu, wchodzi w interakcje z białkiem błony wewnętrznej DotM (IcmP) [31, 32, 33]. Białko DotM przypuszczalnie odpowiada za stabilizację struktury systemu Dot/lcm. Białka DotL i DotM są stabilne jedynie wtedy, gdy są z sobą połączone, a stabilność tego połączenia wzmacnia obecność małego, bogatego w cysteinę białka DotN [34].

Innym elementem kompleksu białek sprzęgających typu IV jest białko LvgA, które wchodzi w interakcje z co najmniej czterema białkami efektorowymi (VpdB, SidH, SetA i PieA) L. pneumophila. Białko LvgA definiowane jest jako białko adaptorowe systemu Dot/lcm, ponieważ jest wymagane do przyłączenia wymienionych białek efektorowych do kompleksu sprzęgającego. Efektory $\mathrm{VpdB}$ i SidH mają wspólny motyw FxxxK, do którego wiąże się białko LvgA. Motyw ten nie występuje w SetA i PieA, co wskazuje na zdolność rozpoznawania przez białko LvgA innych motywów wiążących [35]. Kompleks DotL-IcmSW-LvgA nie wykazuje wykrywalnej interakcji z innymi efektorami, takimi jak białka SidJ lub Lpg039319. Hydrofobowa powierzchnia białka LvgA zawierającego w swej strukturze swoistą wklęsłość z łatwością wiąże kompleks IcmSW. Powierzchnia białka LvgA po przeciwnej stronie zawiera hydrofobową strukturę przypominającą kieszeń, która umożliwia wiązanie się z białkami efektorowymi [29, 35].

Białka adaptorowe IcmS i IcmW działają analogicznie do białek opiekuńczych III systemu sekrecji. Są to małe, rozpuszczalne w cytozolu białka o charakterze kwasowym, które wiążą substraty i pełnią różne funkcje. Należą do nich stabilizacja substratów oraz zapobieganie ich agregacji w cytoplazmie bakterii, a także utrzymanie substratów w stanie gotowym do wydzielania [36]. Jednak nie są to funkcje przypisane wszystkim białkom adaptorowym typu IV L. pneumophila, np. substraty należące do rodziny SidE i SidG są stabilne i nie agregują przy braku obecności kompleksu IcmSW [37].

Masa molekularna stabilnego kompleksu białkowego IcmSW wynosi około $85 \mathrm{kDa}$, a prawdopodobna stechiometria IcmS do IcmW w kompleksie wynosi 2:1 [37]. Kompleks ten odpowiada za przyjmowanie odpowiedniej konformacji przez substraty wydzielnicze systemu Dot/lcm, która umożliwia wiązanie się substratu z białkiem sprzęgającym DotL [13]. Domena umiejscowiona w pobliżu C-końca białka DotL bezpośrednio wiąże kompleks IcmSW, a interakcja ta jest głównym etapem w procesie dostarczania efektorów zależnych od IcmSW przez kanał translokacyjny systemu Dot/lcm. Kompleks IcmSW wiąże substrat w cytoplazmie i utrzymuje go w stanie gotowym do procesu translokacji. Następnie substrat za pośrednictwem C-terminalnej sekwencji stanowiącej sygnał translokacyjny łączy się z białkiem DotL i przemieszcza się w kierunku membrany wewnętrznej. Białko DotL wiąże się bezpośrednio z białkiem błony wewnętrznej DotM. Po wprowadzeniu substratu do kanału translokacyjnego kompleks IcmSW zostaje odłączony od substratu przez reakcję z domeną białka DotL przystosowaną do wiązania kompleksu IcmSW. Prawdopodobnie etap ten przebiega jednocześnie z aktywnym procesem wydzielania substratu poza komórkę bakterii. Uwolniony od białka DotL kompleks IcmSW opuszcza błonę wewnętrzną i przemieszcza się do cytoplazmy komórki bakterii, by powtórnie uczestniczyć w oddziaływaniu z nowymi substratami, a tym samym ukończyć cykl eksportu białek [20].

Białkowe efektory L. pneumophila transportowane przez kanał translokacyjny systemu sekrecji Dot/lcm zawierają swoiste sekwencje sygnalne. Na przykład białko RalF zawiera C-terminalną sekwencję $\mathrm{z}$ podstawnikami leucyny lub innymi aminokwasami o hydrofobowym charakterze [38]. Inną sekwencjąsygnalnąjestmotywE-bloku(EExxE)umiejscowiony w pobliżu C-końca białka efektorowego SidM [34, 39]. Motyw ten przypuszczalnie jest rozpoznawany przez system Dot/ Icm za pośrednictwem podjednostki białka DotM, która zawiera miejsca służące jako platforma wiążąca sekwencje E-bloku [40]. Niedawno zidentyfikowanym motywem jest umieszczony na C-końcu a helisy białek adaptorowych m.in. VpdB i SidH motyw FxxxLxxxK rozpoznawany przez białko LvgA [35]. Wśród 2930 opisanych białek L. pneumophila szczep Philadelphia-1, 257 białek zawiera motyw o sekwencji FxxxLxxxK. Spośród nich 46 białek, w tym białka SidH i VpdB, należą do 280 znanych efektorów $L$. pneumophila, wskazując na powszechne występowanie tego motywu w białkach podlegających translokacji przez kanał systemu T4SS [17].

Optymalny eksport większości substratów systemu Dot/ Icm, m.in. SdeA, SidG, SidH, AnkD, AnkG, PieA, PppA, PpgA, VipA i WipA, jest uzależniony od etapu wiązania się tych substratów z kompleksem IcmSW. Spośród 34 substratów systemu Dot/lcm 24 z nich wymaga obecności IcmS i/lub IcmW do optymalnego eksportu. Uważa się jednak, że zależna od kompleksu IcmSW translokacja większości substratów systemu Dot/lcm przy braku obecności tego kompleksu jest możliwa, ale przebiega ze znacznie zmniejszoną efektywnością [20]. Prawdopodobnie jest to możliwe dzięki interakcjom m.in. z elementami systemu sekrecji, które ułatwiają rozpoznanie substratów białkowych i ich wprowadzenie do kanału translokacyjnego systemu Dot/ Icm. Eliminacja pojedynczego komponentu systemu sekrecji pośredniczącego w rozpoznawaniu substratu może wpłynąćna wydajność translokacji białka, ale nie powoduje jej całkowitego 
zahamowania, o ile substrat białkowy zachowuje zdolność do interakcji z innymi składnikami systemu. Przykładem takiej zależności jest translokacja białka RalF, które nie wiąże się $z$ kompleksem IcmSW, a mimo to jest transportowane $z$ dużą wydajnością dzięki interakcji z białkiem DotF [24].

Kompleks IcmSW ma podstawowe znaczenie w procesie translokacji substratów systemu Dot/lcm do cytoplazmy komórki gospodarza. Usunięcie domeny białka DotL wiążącej kompleks IcmSW nie zaburza procesu powstawania funkcjonalnego systemu T4SS, a także nie wpływa na zmianę stabilności DotL w fazie wzrostu L. pneumophila, która obserwuje się $w$ razie braku białka IcmS. Jednak mutanty L. pneumophila niezdolne do syntezy białka DotL wykazują defekt w procesie eksportu substratów zależnych od kompleksu IcmSW [20]. Brak syntezy biakek IcmS i IcmW powoduje, że białko sprzęgające DotL jest destabilizowane i degradowane w sposób zależny od wysoce konserwatywnej proteazy rdzeniowej ClpA podczas przejścia bakterii z fazy wzrostu eksponencjalnego do fazy stacjonarnej $L$. pneumophila. Degradacja białka DotL może być także spowodowana nieprawidłową interakcją między tym białkiem a translokowanymi substratami. Dotyczy to szczególnie substratów zależnych od kompleksu IcmSW, które z powodu braku obecności białek adaptorowych typu IV wykazują defekt łączenia się z białkiem DotL. Zaburza to mechanizm sekrecji, a nieprawidłowo złożony kompleks kierowany jest na szlak odpowiedzi komórki na warunki stresowe angażujący proteazę ClpA [28].

\section{Składniki stabilizujące rdzeń kompleksu}

Integralnymi białkami błony wewnętrznej, które po raz pierwszy zidentyfikowano w IV systemie L. pneumophila, są białka DotU/IcmH i IcmF. Białka homologiczne do białek DotU i IcmH występują powszechnie u bakterii należących do Proteobacteria, a kodujące je geny są powiązane z klastrem genów kodujących konserwatywne białka homologiczne IcmF (IAHP, IcmF-associated homologous proteins). Białka DotU/lcmH i IcmF wykazują podobieństwo do białek systemu sekrecji typu VI, odpowiednio TssL i TssM, w umiejscowieniu w błonie wewnętrznej, topologii białka oraz wzajemnej interakcji i stabilizacji. Mimo braku podobieństwa pierwotnej sekwencji białek TssL i IcmH/DotU, oba białka należą do rodziny DUF2077 (Pfam PF09850). Zawierają podobną drugorzędową strukturę i przypuszczalnie porównywalny sposób pofałdowania struktury białka [41].

Białka DotU i IcmF kodowane przez sąsiadujące ze sobą na chromosomie L. pneumophila geny $\operatorname{dot} U \mathrm{i} i c m F$ odpowiadają za optymalny wewnątrzkomórkowy wzrost bakterii. Utrata pojedynczego genu dotU, icmF lub obu genów jednocześnie podobnie zaburza wewnątrzkomórkową replikację $L$. pneumophila. Przypuszczalną funkcją białek DotU i IcmF jest stabilizacja systemu Dot/lcm, gdyż mutacja w genach $\operatorname{dot} U$ i icmF wpływa na zmniejszenie stabilności białek błony zewnętrznej kompleksu rdzeniowego - DotF, DotG i DotH. Dochodzi wówczas do zmniejszenia liczby komponentów rdzenia systemu Dot/lcm, szczególnie białek DotH i DotG, a to zmniejsza aktywność całego układu. W badaniach z wykorzystaniem mutantów defektywnych w syntezie biakek DotU i IcmF zastosowanie nadekspresji jedynie białka DotH przywraca zdolność do wewnątrzkomórkowej replikacji bakterii. Wskazuje to na współdziałanie białek DotU i IcmF w zapobieganiu degradacji białka DotH, a tym samym stabilizacji kompleksu rdzeniowego systemu T4SS L. pneumophila. Ponadto białka te określane są także jako czynniki pomocnicze systemu T4SS, które chronią go przed destabilizacją i degradacją w procesie selektywnej proteolizy przez niezidentyfikowaną jak dotąd proteazę, przy przejściu $L$. pneumophila z fazy wzrostu wykładniczego do stacjonarnego [34].

\section{Składniki cytoplazmatyczne}

Białka cytoplazmatyczne $L$. pneumophila niezbędne do prawidłowego działania systemu Dot/lcm to IcmR oraz IcmQ [21]. IcmR to małe białko (10-15 kDa) o kwasowym charakterze (punkt izoelektryczny wynosi około 4,5) zawierające hydrofobową a helisę w domenie C-terminalnej. Białko IcmR pełni funkcję białka opiekuńczego dla białka IcmQ, zapobiega jego agregacji oraz interakcji z innymi białkami [38]. Brak białka IcmR u L. pneumophila powoduje pojawienie się agregatów IcmQ w postaci dwóch kompleksów o masie molekularnej 500 i $60 \mathrm{kDa}$. Białko IcmQ może tworzyć homopolimery o różnej liczbie cząsteczek, jednak regulacja stanu oligomeryzacji kompleksów IcmQ pozostaje nieznana. Białko IcmR może doprowadzić do dysocjacji istniejącego już agregatu białek IcmQ nawet przy braku ATP. Prawdopodobnie dzieje się tak, gdyż wzajemne oddziaływanie między cząsteczkami IcmQ $w$ agregacie jest dynamiczne i ma mniejsze powinowactwo w porównaniu z oddziaływaniem z białkiem IcmR. Nie udało się dotąd udokumentować takiej cechy u białek opiekuńczych należących do systemu sekrecji, nawet u białek opiekuńczych zależnych od ATP [38].

W badaniach in vitro wykazano, że oczyszczone białko IcmQ wiąże się ze sztucznie utworzonymi pęcherzykami lipidowymi, powodując ich pękanie. Mechanizm tego procesu opiera się na elektrostatycznym oddziaływaniu domeny C-końcowej białka IcmQ (Qc), która umożliwia oddziaływanie całego białka z błoną pęcherzyka. Następnie dochodzi do wstawienia domeny N-końcowej białka IcmQ (Qn) do dwuwarstwy lipidowej pęcherzyków i zniszczenia struktury błony. Domena Qn wiąże się także z białkiem 
IcmR, zapobiegając stabilnemu związaniu się białka IcmQ z błoną pęcherzyka. Dlatego przy braku białka IcmR występuje istotny wzrost białka IcmQ umiejscowionego w błonach L. pneumophila. Prawdopodobnie białko IcmR pełni funkcję regulacyjną $w$ stosunku do białka IcmQ [8]. Domena Qc białka IcmQ zawiera miejsce wiązania dinukleotydu nikotynoamidoadeninowego, a to powoduje, że kompleks IcmR-IcmQ w połączeniu z NAD+, po związaniu z błonami, wspomaga stabilizację lub modyfikację tego białkowego kompleksu w aparacie sekrecyjnym Dot/lcm. Przypuszcza się, że białko IcmQ może być wyspecjalizowaną rybozylotransferazą ADP (ADPRT, ADP ribosyltransferases), która modyfikuje komponenty systemu T4SS [42, 43]. Wiązanie $\mathrm{NAD}^{+}$przez białko IcmQ może stabilizować domenę Qc, umożliwiając działanie tego białka przez interakcję ze składnikami systemu T4SS. Blokowanie wiązania $\mathrm{NAD}^{+}$narusza stabilność białka IcmQ. Domena Qc może działać jako sensor, który umożliwia kompleksowi IcmR-IcmQ interakcję z krytycznym składnikiem systemu sekrecji, podczas gdy wewnątrzkomórkowy poziom $\mathrm{NAD}^{+}$jest wystarczający do zajścia reakcji wiązania. Niski wewnątrzkomórkowy poziom $\mathrm{NAD}^{+}$prowadzi w tym przypadku do zwiększonego tempa zużycia białka IcmQ, co może nastąpić w czasie wzrostu bakterii, w którym poziom innych białek związanych z wirulencją jest również obniżony [44]. Kompleks IcmR-IcmQ wiąże się z błonami zawierającymi kwaśne fosfolipidy [8]. Białko IcmQ podczas łączenia się z membranami przypuszczalnie wykorzystuje dwie reszty argininy występujące $w$ helisie łączącej struktury białka. Mutacje w genach kodujących te cząsteczki argininy powodują prawie $50 \%$ utratę zdolności do translokacji białek za pomocą systemu Dot/lcm bez wpływu na poziom ekspresji białka IcmQ L. pneumophila [42].

Białkiem cytoplazmatycznym niezbędnym do prawidłowego funkcjonowania systemu Dot/lcm jest białko DotB, które pełni funkcję ATPazy [45, 46]. Obecność niewielkich ilości białka DotB stwierdza się także we frakcji błon wewnętrznych L. pneumophila. Białko DotB przyjmuje formę heksamerycznego, wbudowanego w błonę pierścienia o charakterze hydrofilowym. Formowanie się struktury pierścienia nie jest zależne od wiązania ATP. DotB ma konserwatywny motyw Walkera oraz domeny: N-końcową oddziałującą z błoną komórkową, C-końcową o nieustalonej dotąd funkcji oraz domenę ATPazy. Białko DotB jest zaangażowane w sekrecję białek efektorowych za pomocą systemu Dot/lcm [47]. Ekspresja genów kodujących białka DotB oraz DotC zwiększa się po upływie 24 godzin od infekcji komórek Acanthamoeba castellanii przez L. pneumophila [48].

Do białek cytoplazmatycznych o aktywności ATPazy należy także białko DotO/lcmB, którego masa molekularna wynosi 112 kDA. DotO ma postać dimerów, które tworzą układ heksameryczny budujący centralny kanał translokacyjny zakotwiczony w błonie wewnętrznej. W domenie C-końcowej białko DotO zawiera motyw Walkera A oraz B służący do wiązania nukleotydów. Podobny układ występuje także w białku VirB należącym do systemu T4ASS, które wykazuje słabą homologię do białka DotO. Kompleks DotO-DotB jest zaangażowany w zmianę konformacji kanału translokacyjnego w błonie wewnętrznej. Białko DotB w postaci niezwiązanej z DotO przypomina cylinder w kształcie litery $V$ leżący nad białkiem DotO, którego węższy koniec skierowany jest do cytoplazmy komórki. Kanał translokacyjny jest wtedy zamknięty. Po związaniu się białka DotB z DotO dochodzi do obrotu struktury heksamerycznej DotO o około 20 stopni i zmiany konformacji białka DotB, które przyjmuje kształt otwartego cylindra. W wyniku tej modyfikacji następuje otwarcie kanału translokacyjnego. Związanie DotB z DotO jest podstawowym etapem wczesnej translokacji efektorów aparatu Dot/lcm [49].

\section{Pozostałe komponenty aparatu Dot/lcm}

Do pozostałych białek systemu Dot/lcm umiejscowionych w błonie wewnętrznej należy DotE oraz zidentyfikowane wyłącznie u bakterii z rodzaju Legionella białko DotV. Białka te zawierają cztery transmembranowe helisy, które pod względem organizacji domen w strukturze wykazują podobieństwo do białka TraQ, należącego do systemu koniugacji typu I. Białko DotP jest podobne do białka DotE/DotV, ma przy N-końcowej domenie sekwencję sygnałową, zdolną do odłączenia się od białka, oraz dwie transmembranowe helisy [50].

Innym białkiem błony wewnętrznej jest Dotl, które wykazuje znaczne podobieństwo sekwencji aminokwasowej do białka TraM kodowanego przez gen umiejscowiony na plazmidzie koniugacyjnym R64 oraz podobieństwo struktury domeny C-końcowej do białka VirB8 systemu T4ASS. W warunkach in vivo białka Dotl i VirB6 mogą tworzyć oligomeryczne pierścienie ułożone w postaci stosu [51]. Poziom syntezy białka Dotl jest powiązany z poziomem syntezy jego białkowego homologu DotJ. Białka te wykazują podobieństwo w N-końcowej domenie, ale DotJ nie ma domeny peryplazmatycznej. Białka Dotl i DotJ tworzą heterokompleks w błonie wewnętrznej w stosunku molekularnym 1,87:1 (Dotl:DotJ). Kompleks ten przyjmuje formę pierścienia otaczającego kanał, przez który odbywa się transport substratów. Aktywność kompleksu białek DotlJ może być związana z ATPazą DotO [52]. Białko Dotl jest obecne we wszystkich poznanych jak dotąd systemach T4BSS u bakterii. Natomiast DotJ zidentyfikowano jedynie u bakterii należących do rzędu Legionellales [51]. Innym białkiem umiejscowionym w obrębie błony wewnętrznej, a którego obecność wykazano tylko u bakterii z rodzaju Legionella, jest DotA. Białko to składa się z ośmiu domen 
spinających błony, dwóch dużych domen peryplazmatycznych (zbudowanych z około 503 i 73 aminokwasów) oraz jednej małej cytoplazmatycznej domeny C-końcowej (składającej się z 122 aminokwasów). Białko DotA zawiera także sekwencję sygnalną, która może się odłączyć od struktury białka. Domena peryplazmatyczna DotA jest umiejscowiona w górnej części centralnego kanału translokacyjnego i odpowiada za stabilizację jego ścian lub może zostać uwolniona [53]. Rozmieszczenie domen transmembranowych w strukturze DotA jest podobne do białek transporterowych typu $A B C$ $[54,55]$. Strukturalne podobieństwo wskazuje na możliwość oddziaływania białka DotA z innymi białkami, jako część kompleksu odpowiedzialnego za dostarczanie substratów do fagosomów we wnętrzu makrofagów. Potwierdza to wykazana zdolność wiązania się białka DotA z innym białkiem o niepoznanej dotąd funkcji, którego masa molekularna wynosi $46 \mathrm{kDa}$. W środowisku zewnątrzkomórkowym białko to razem z białkiem DotA tworzy oligomer przypominający pierścień [50]. Domena cytoplazmatyczna białka DotA przypuszczalnie pełni funkcję łącznika między białkami przenoszącymi energię w cytoplazmie i środowisku zewnątrzkomórkowym. Badania z wykorzystaniem mutantów L. pneumophila niezdolnych do wewnątrzkomórkowego namnażania się wykazały, że istnieje co najmniej jedno białko wiążące nukleotydy, którego funkcją jest przeniesienie energii do kompleksu zawierającego białko DotA [53].

Innym komponentem systemu Dot/lcm umiejscowionym w błonie zewnętrznej jest lipoproteina DotK [56]. Białko to zakotwicza system Dot/lcm w warstwie peptydoglikanu ściany komórkowej bakterii. Mutanty $L$. pneumophila defektywne w syntezie białka DotK nie namnażają się w komórkach ameb $A$. castellanii, ale nie tracą tej zdolności w makrofagach [18]. Składnikiem aparatu Dot/lcm jest peryplazmatyczne białko IcmX, dokładnej funkcji tego białka jeszcze nie poznano. Wiadomo, że jego brak wywołuje defekt wewnątrzkomórkowego namnażania się L. pneumophila, ale $w$ dalszym ciągu możliwy jest proces składania systemu T4SS [40].

Do pozostałych białkowych komponentów systemu Dot/lcm o niepoznanych jak dotąd funkcjach należą małe integralne białka błony wewnętrznej IcmT oraz IcmV. Ortologi białka IcmT występują w wielu bakteryjnych systemach T4SS i w systemie koniugacyjnym typu I (TraK) [50]. Geny kodujące białko $\mathrm{IcmV}$, podobnie jak białek $\mathrm{IcmW}$ i $\mathrm{IcmF}$, zawierają region, który przypuszczalnie służy wiązaniu regulatorowych czynników transkrypcyjnych [57].

\section{Wpływ efektorów systemu Dot/lcm na przebieg procesów życiowych komórki gospodarza}

\section{Modulowanie transportu pęcherzykowego}

W procesie adhezji i pobierania przez makrofagi $L$. pneumophila jest zaangażowane białko SdeA, a sam proces internalizacji jest niezbędny do zainicjowania translokacji wstępnie zsyntetyzowanych białek efektorowych [58]. Otoczona pojedynczą błoną wakuola, tzw. fagosom, w którym zostają zamknięte bakterie, w ciągu pierwszych 15 min zostaje pokryta wczesnymi pęcherzykami wydzielniczymi uwolnionymi $z$ retikulum endoplazmatycznego (ER), a to uniemożliwia jej przekształcenie w wakuolę trawienną. Wyrazem blokady procesu dojrzewania fagosomu wypełnionego bakteriami jest brak łączenia się markerów endocytarnych, takich jak lizosomalne glikoproteiny związane z błoną LAMP-1 i LAMP-2 (LAMP, lysosomal-associated membrane protein) lub kwaśna lizosomalna proteaza - katepsyna D z błoną fagosomu [15]. Unikanie fuzji z lizosomami oraz rekrutacja pęcherzyków ER do membrany fagosomu odbywa się za pośrednictwem systemu Dot/lcm, który dzięki wprowadzeniu substratów efektorowych bezpośrednio do komórki gospodarza moduluje proces biogenezy fagosomów [36, 59, 60, 61, 62]. Białko DotA, syntetyzowane na wczesnych etapach infekcji, przed fagocytozą bakterii przez makrofagi, uczestniczy w blokowaniu fuzji błony fagosomu zawierającego bakterie Legionella z lizosomami. Mutanty L. pneumophila niezdolne do syntezy białka DotA już po 5 min od wniknięcia do komórki makrofaga zostają otoczone przez białka pochodzenia lizosomalnego LAMP-1 i Rab7, co wskazuje na zasadniczą rolę białka DotA w modulowaniu wstępnych etapów interakcji fagosomu ze szlakiem endocytarnym gospodarza [53]. Podczas otaczania fagosomu przez membrany retikulum endoplazmatycznego następuje zagęszczenie mitochondriów wokół wakuoli zawierającej pałeczki Legionella. Jedynym poznanym jak dotąd substratem wydzielanym przez system Dot/lcm, który może się swoiście wiązać z mitochondriami gospodarza, jest białko efektorowe Leg2S. Białko to jest wysoce konserwatywnym eukariotycznym homologiem enzymu liazy sfingozyno-1-fosforanu (SPL), kierowanym do mitochondriów komórek linii COS-7 i przypuszczalnie wpływającym na metabolizm sfingolipidów. Białko efektorowe LegS2 degraduje sfingozyno-1-fosforan (S1P) m.in. do fosfoetanoloaminy będącej prekursorem syntezy fosfatydyloetanoloaminy [63]. Błona otaczająca wakuolę wypełnioną $L$. pneumophila jest bogata w 4-fosforan 
fosfatydylo-mio-inozytolu (PI-4P), który jest pozyskiwany z pęcherzyków aparatu Golgiego gospodarza [13]. PI jest podstawową klasą lipidów błonowych, które mogą ulegać odwracalnej fosforylacji w pozycjach 3,4 i/lub 5 pierścienia inozytolu. Każdy z tych lipidów charakteryzuje się unikalnym rozmieszczeniem w komórce. Przekształcanie PI jest ściśle regulowane w czasie i przestrzeni przez kinazy PI i fosfatazy. Znanych jest 14 efektorów L. pneumophila, które swoiście wiążą PI3P i/lub PI4P. Domeny wiążące PI są umiejscowione na C-końcach efektorów, są małe i zawierają około 100 aminokwasów, podobnie jak domeny białek eukariotycznych, które wiążą PI [64]. Białka efektorowe wydzielane przez $L$. pneumophila mogą bezpośrednio modyfikować poziom PI w komórce gospodarza, zmieniać aktywność enzymów metabolizujących PI lub wiązać się z PI w celu ich właściwego wewnątrzkomórkowego przekierowania.

Manipulacja transportu pęcherzykowego przez pałeczki L. pneumophila polega na kontrolowaniu szlaków guanozyno-5'-trifosforanu (GTP) komórki gospodarza oraz zakłócania aktywności GTPaz, które odgrywają decydującą rolę $w$ regulacji dynamiki organelli oraz koordynowaniu sygnalizacji wewnątrzkomórkowej, działając jako molekularne przełączniki. Ważnym elementem strategii wewnątrzkomórkowego namnażania się L. pneumophila jest zdolność do manipulowania funkcją małych GTPaz, należących do rodzin Rab, Arf, Ran i Rap. Analizy proteomiczne wykazały, że duża liczba GTPaz Rab (Rab1, $2,4,5,6,7,8,10,11,14,18,21,31$ i 32) jest rekrutowana do błony wakuoli wypełnionej bakteriami Legionella [65, 66, 67, 68, 69]. Zwłaszcza białko Rab1 jest zaangażowane w kontrolę transportu pęcherzyków między ER i odpowiednim przedziałem aparatu Golgiego. Białko Rab1 jest rekrutowane do fagosomu zaledwie kilka minut od pobrania bakterii przez komórkę gospodarza [70]. Następnie aktywność tego białka jest regulowana przez serię potranslacyjnych modyfikacji za pośrednictwem efektorów systemu Dot/lcm. W rekrutację i aktywację białka Rab1 zaangażowany jest efektor SidM/ DrrA, który zawiera trzy funkcjonalne domeny [62]. Po translokacji białka domena P4C umiejscowiona w C-końcowej części SidM wiąże się z PI(4)P i w ten sposób zakotwicza białko $\mathrm{w}$ błonie fagosomu, gdzie rekrutuje i aktywuje białko Rab1, wykorzystując w tym celu domenę czynnika wymiany nukleotydów guanininowych (GEF). N-końcowa domena białka SidM wykazuje aktywność ligazy E3 ubikwityny, a związanie się białka z $\mathrm{PI}(4) \mathrm{P}$ indukuje zmianę konformacji białka z zamkniętej w otwartą [24, 55]. Białko Rab1 w postaci związanej z inhibitorem dysocjacji nukleotydów guaninowych (Rab1-GDI) zostaje przekierowane do membrany fagosomu. Domena o aktywności adenylotransferazy białka SidM modyfikuje białko Rab1 przez przeniesienie adenozyno monofosforanu (AMP) z adenozyno trójfosforanu (ATP) do reszty tyrozyny (Tyr77) w łańcuchu bocznym. Kowalencyjne przyłączenie reszty AMP zapobiega dezaktywacji białka Rab1 przez białko aktywujące GTPazę (GAP) LepB oraz TBC1D20. Po upływie około 2 godzin od chwili wniknięcia bakterii do komórki gospodarza, białko SidD powoduje usunięcie reszty AMP z cząsteczki Rab1, przez co staje się dostępna dla białka LepB stymulującego aktywność GTPazy. Inaktywowane białko Rab1 w połączeniu z niezidentyfikowanym dotąd inhibitorem GDI opuszcza membranę fagosomu zawierającego pałeczki Legionella $[6,71,72,73]$ (ryc. 3). W regulacji aktywności białka Rab1 uczestniczy również efektor AnkX, który bezpośrednio modyfikuje białko przez kowalencyjne przyłączenie reszty fosfocholiny pochodzącej z CDP-choliny. Obecność grupy fosfocholinowej powoduje zahamowanie interakcji białka Rab1 z GEF i GAP, a skutkiem tego jest zakłócenie transportu pęcherzyków na mikrotubulach wkrótce po ich uwolnieniu z ER. Ponadto efektor SidE, który wykazuje aktywność ADPrybozylotransferazy, umożliwia przyłączenie ubikwityny do białka Rab1 w procesie niezależnym od kaskady enzymów E1, E2 i E3 [30, 74, 75, 76].

Duże GTPazy, np. atlastyna-3 (Atl3/Sey1), która jest dynaminopodobnym białkiem umiejscowionym w cysternach $\mathrm{ER}$, kontroluje przebudowę retikulum podczas dojrzewania wakuoli zawierającej bakterie Legionella [77]. Natomiast mitochondrialna dynamina (Dnm11) powoduje fragmentację mitochondriów i nagłe zatrzymanie oddychania komórkowego pod wpływem efektora MitF [78]. W rekrutację białka Rab1 jest zaangażowane również białko LidA, którego translokacja do membrany fagosomu zachodzi bezpośrednio po kontakcie L. pneumophila z komórką makrofaga [79]. Poza Rab1 białko LidA wiąże również Rab 6 i 8 . W rekrutację białka Arf1 do błony wakuoli zaangażowane jest białko efektorowe RalF [80, 81, 82] (tab. 1).

\section{Zakłócenie procesu biosyntezy białka, autofagii i apoptozy}

Poza modulowaniem transportu pęcherzykowego efektory systemu Dot/lcm wpływają na przebieg wielu procesów komórkowych gospodarza, takich jak biosynteza fosfolipidów, funkcjonowanie cytoszkieletu, dynamika mitochondriów, apoptoza czy autofagia (tabela 1).

Błona wakuoli wypełnionej bakteriami L. pneumophila wykazuje cechy wspólne dla autofagosomów, w tym ich ścisły związek z błoną ER, co sugeruje ingerowanie w maszynerię autofagii w procesie formowania niszy replikacyjnej. Białko efektorowe RavZ L. pneumophila o aktywności proteazy cysteinowej hydrolizuje wiązanie amidowe między C-końcową glicyną i sąsiednim aminokwasem aromatycznym białka Atg8, które w połączeniu z fosfatydyloetanoloaminą tworzy kompleks odpowiedzialny za dynamikę 


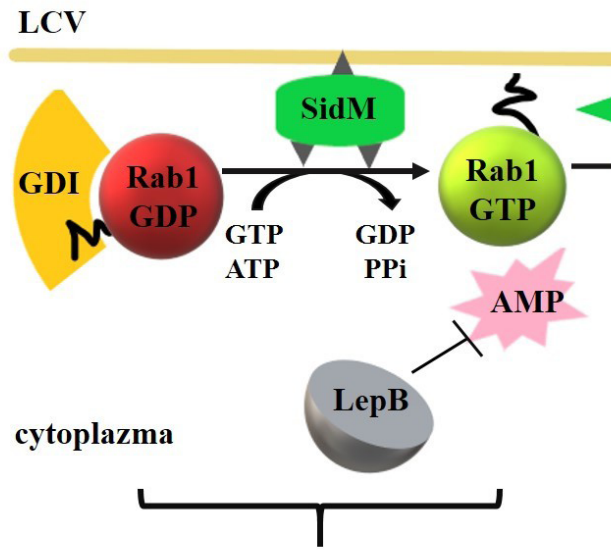

Pierwsze 2 godziny infekcji

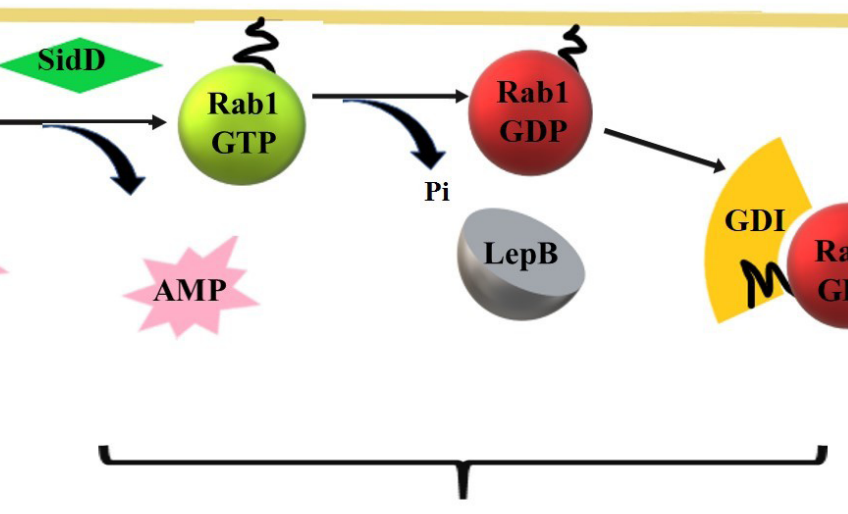

Po uplywie 2 godzin infekcji

Rycina 3: Schemat regulacji aktywności białka Rab1 przez efektory systemu Dot/lcm

L. pneumophila. W ciągu pierwszych dwóch godzin infekcji komórki gospodarza białko efektorowe SidM związane z błoną wakuoli replikacyjnej zawierającej pałeczki Legionella (LCV) doprowadza do odłączenia białka Rab1 od inhibitora dysocjacji nukleotydów guaninowych (GDI), a następnie modyfikuje Rab1 przez przeniesienie adenozynomonofosforanu (AMP). Zmodyfikowane białko Rab1 pozostaje w stanie aktywnym, gdyż zdolność jego wiązania się z białkami aktywującymi GTPazę (np. LepB) zostaje zablokowana. Po dwóch godzinach infekcji białko efektorowe SidD powoduje usunięcie reszty AMP z cząsteczki Rab1, przez co staje się ona dostępna dla białka LepB stymulującego aktywność GTPazy. Inaktywowane białko Rab1 w połączeniu z GDI opuszcza membranę wakuoli LCV

błony autofagosomalnej. Nieodwracalna inaktywacja białek Atg8 sprawia, że nie dochodzi do utworzenia systemu koniugacyjnego z białkami Atg3 i Atg7, w wyniku czego następuje kontrolowane zahamowanie procesu autofagii [86]. W inhibicji autofagii uczestniczy również białko $L p S p l L$. pneumophila, które wykazuje homologię do eukariotycznej liazy fosforanu sfingozyny, enzymu precyzyjnie regulującego poziom fosforanu sfingozyny zaangażowanego w stymulację autofagii. Aktywność enzymu LpSpl skutecznie obniża poziom komórkowej sfingozyny i w ten sposób opóźnia autofagiczną odpowiedź gospodarza podczas infekcji mysich makrofagów płuc [63]. Inne białko Lpg1137 o aktywności proteazy serynowej degraduje umiejscowioną w błonie ER związanego z mitochondriami syntaksynę 17 (STX17) zaangażowaną w proces dojrzewania autofagosomu i w ten sposób blokuje autofagię [20]. Sposób wzajemnego oddziaływania efektorów hamujących autofagię oraz strategiczna przewaga obecności kilku supresorów wymagają wyjaśnienia.

W inicjacji mechanizmów obronnych gospodarza podczas bakteryjnej infekcji gromadzone są inflamasomy, czyli wielobiałkowe kompleksy, które działają jak molekularna platforma do rekrutacji i aktywacji kaspaz. Inflamasomy powstają w odpowiedzi na obecność flageliny rzęski, która jest transportowana do cytozolu komórki gospodarza z wakuoli, w której występują L. pneumophila za pośrednictwem IV systemu sekrecji. Bogaty w leucynę C-koniec o strukturze spinki do włosów flageliny zostaje związany przez czynnik NAIP5, a utworzony kompleks oddziałuje z NLRC4, tworząc funkcjonalny inflamasom aktywujący kaspazę-1. Kaspaza-1 przekształca cytokiny IL-1ß i -18 w ich dojrzałe, aktywne postaci i dochodzi do reakcji zapalnej, pojawienia się kanałów w membranie makrofagów aż do śmierci komórki w wyniku pyroptozy. L. pneumophila wykorzystuje różne strategie, które swoiście opóźniają lub hamują szlaki apoptozy gospodarza w celu zapewnienia optymalnych warunków namnażania. Bakterie L. pneumophila uwolnione ze struktur biofilmu wytwarzają znacznie mniej białka flageliny, co pozwala uniknąć aktywacji czynnika NLRC4 [67]. Białko SdhA jest wydzielane do cytozolu komórki wkrótce po pobraniu L. pneumophila i stale jest syntetyzowane podczas wewnątrzkomórkowej replikacji bakterii [53]. Naruszenie integralności błony wakuoli u mutantów niezdolnych do syntezy białka SdhA uwalnia L. pneumophila do cytozolu makrofagów, gdzie bakterie narażone są na działanie przeciwbakteryjnych białek z rodziny GBP, a czego skutkiem jest uwolnienie LPS ze ściany komórkowej bakterii i aktywacja kaspazy-11. Gasdermina D tworzy kanały w błonie i dochodzi do śmierci komórki w procesie pyroptozy [50]. Celem działania efektora SidF są proapoptyczne białka BNIP i Bcl-Rambo, należące do rodziny Bcl-2 [88]. Jedna z domen tego białka wykazuje aktywność fosfatydyloinozytolo-3-fosfatazy, która swoiście hydrolizuje $\mathrm{PI}(3,4) \mathrm{P} 2$ i PI(3,4,5)P3 i uczestniczy w wzbogaceniu błony fagosomu w $\mathrm{PI}(4) \mathrm{P}$, umożliwiając zakotwiczenie innych efektorów systemu Dot/lcm.

L. pneumophila indukuje również ekspresję kilku genów antyapoptotycznych gospodarza przez aktywację jądrowego czynnika transkrypcyjnego NF-kB, który odgrywa główną rolę $\mathrm{w}$ regulacji transkrypcji i aktywacji wrodzonej odpowiedzi 


\begin{tabular}{|c|c|}
\hline $\begin{array}{c}\text { Efektor } \\
\text { Interakcja bakterii z re }\end{array}$ & $\begin{array}{l}\text { Źródło } \\
\text { nym i utworzenie LCV }\end{array}$ \\
\hline SidM/DrrA & [83] \\
\hline SidD & [9] \\
\hline LepB & {$[9,84]$} \\
\hline AnkX & [49] \\
\hline LidA & [85] \\
\hline RalF & {$[80,81]$} \\
\hline MitF & [23] \\
\hline \multicolumn{2}{|c|}{ Zakłócenie procesu autofagii } \\
\hline RavZ & [86] \\
\hline$L p / S p l$ & [61] \\
\hline \multicolumn{2}{|c|}{ Modulacja procesu apoptozy } \\
\hline SdhA & [87] \\
\hline SidF & [88] \\
\hline LegS2 & [61] \\
\hline \multicolumn{2}{|c|}{ Wpływ na działanie kinaz } \\
\hline LegK1 & {$[67,89]$} \\
\hline LnaB & [67] \\
\hline MavC & {$[11,57]$} \\
\hline SidL & [5] \\
\hline Lgt1 & [5] \\
\hline Lgt2 & [5] \\
\hline Lgt3 & [5] \\
\hline Sidl & [5] \\
\hline Ceg4 & [36] \\
\hline \multicolumn{2}{|c|}{ Zakłócenie biosyntezy białka } \\
\hline RomA & [75] \\
\hline SnpL & [63] \\
\hline
\end{tabular}

Tabela 1. Wybrane efektory systemu Dot/lcm L. pneumophila modulujące przebieg procesów komórki gospodarza immunologicznej gospodarza na infekcję. Białkami aktywującymi NF-KB są efektory LegK1 i LnaB [90]. Białko LegK1 odpowiada za bezpośrednią fosforylację czynnika IkBa, który jest inhibitorem NF-kB. Farmakologiczne blokowanie czynnika jądrowego indukuje apoptozę komórki gospodarza i osłabienie wzrostu L. pneumophila [91]. W początkowej fazie infekcji $L$. pneumophila dochodzi do stłumienia sygnalizacji NF-kB za pośrednictwem transglutaminazy MavC, która katalizuje kowalencyjnie wiązanie ubikwityny do E2 enzymu UBE2N, hamując $w$ ten sposób tworzenie łańcuchów poliubikwitynowych [38, 89, 92]. Natomiast efektor SidL oraz cytotoksyczne glukozylotransferazy Lgt1, Lgt2, Lgt3 wraz białkiem Sidl swoiście obniżają syntezę inhibitora NF-KB [93]. Białko Sidl ma aktywność hydrolazy glikozylowej zależnej od GDP. Jego aktywność jest regulowana przez Mesl, który jest jednym z 20 opisanych u L. pneumophila tzw. metaefektorów modyfikujących działanie innych efektorów. Różne regiony białka Sidl są zdolne do jednoczesnego wiązania się $z$ efektorem Mesl oraz z czynnikiem translacyjnym komórki gospodarza eEF1A, czego skutkiem jest hamowanie translacji białek eukariotycznych [94].

Białko Lgt1 L. pneumophila selektywnie modyfikuje białka gospodarza o masie molekularnej około $50 \mathrm{kDa} z$ użyciem glukozodifosforanu urydyny (UDP-glukozy) jako kosubstratu. Substratem dla tej glukozylotransferazy jest eukariotyczny czynnik elongacyjny eEF1A. Glikozylacja eEF1A powoduje zahamowanie syntezy białka i wywołuje śmierć komórki gospodarza oraz uwolnienie bakterii do otaczającego środowiska i rozpoczęcie kolejnej rundy replikacyjnej [95]. Interakcja Lgt1 z eEF1A jednocześnie indukuje reakcje stresowe w komórce gospodarza, których przejawem jest aktywacja białka regulatorowego szoku cieplnego HSF1 [69]. Ponadto Lgt1 może modyfikować białka szoku cieplnego Hsp70, co może mieć dodatkowy wpływ na indukcję odpowiedzi stresowej w zakażonych komórkach gospodarza [96].

Pięć efektorów L. pneumophila wydzielanych za pomocą IV systemu sekrecji hamuje translację białek gospodarza przez aktywację szlaku kinazy białkowej aktywowanej mitogenami (MAPK), modyfikując w ten sposób odpowiedź transkrypcyjną komórki gospodarza [76]. Fosfataza fosfotyrozynowa Ceg4 zawierająca domenę o aktywności dehalogenazy-hydrolazy halo-kwasowej defosforyluje wiele peptydów zawierających fosfotyrozynę i w ten sposób może osłabić aktywację szlaków kontrolowanych przez MAPK zarówno w komórkach drożdży, jak i ludzkich [44].

L. pneumophila bezpośrednio moduluje maszynerię transkrypcyjną komórki gospodarza, wydzielając efektor RomA, który metyluje resztę lizyny (Lys14) histonu H3, blokując ekspresję genów gospodarza [2]. Innym efektorem, który również celuje w jądro komórki gospodarza, jest SnpL, który wiąże się z eukariotycznym czynnikiem SUPT5SH 
odpowiedzialnym za regulację zależnej od polimerazy II RNA obróbki i elongacji mRNA [41].

\section{Podsumowanie}

Bakterie Legionella pneumophila nabyły rzadką wśród mikroorganizmów zdolność do namnażania się w komórkach fagocytujących, w środowisku naturalnym w wybranych gatunkach pierwotniaków oraz w organizmie człowieka w makrofagach płucnych. Bakterie po przedostaniu się do makrofagów przełamują ich mechanizmy bójcze, powodując rozwój nietypowego zapalenia płuc, zwanego chorobą legionistów. Główną rolę w patogenezie L. pneumophila odgrywa aktywność białek efektorowych wydzielanych za pomocą IV systemu sekrecji Dot/lcm, które kontrolują poszczególne etapy infekcji od chwili pobrania bakterii, zakłócenia przebiegu różnych szlaków komórki gospodarza (przemieszczania się pęcherzyków, syntezy białek, ubikwitylacji, autofagii i apoptozy) aż po ucieczkę z komórki, wktórej drobnoustroje wyczerpały pulę substancji odżywczych. Poznanie w jaki sposób $L$. pneumophila precyzyjnie reguluje w czasie i przestrzeni funkcje poszczególnych efektorów, ma decydujące znaczenie w zapobieganiu i skutecznym leczeniu choroby legionistów.

\section{Wykaz skrótów}

ADP - adenozyno difosforan, ADPRT - rybozylotransferaza ADP, AMP - adenozyno monofosforan, ATP - adenozyno trójfosforan, CTE - C-końcowe podjednostki stanowiące przedłużenia, ER - retikulum endoplazmatyczne, GAP - białko aktywujące GTPazę, GDI - inhibitor dysocjacji nukleotydów guaninowych, GEF - czynnik wymiany nukleotydów guanininowych, GTP - guanozyno-5'-trifosforan, IAHP - białka homologiczne IcmF, LAMP - lizosomalne glikoproteiny związane z błoną, LCTM - kompleks rdzeniowotransmembranowy Legionella, LCV - wakuola replikacyjna Legionella, LT4CP - kompleks białek sprzęgających typu IV Legionella, MAPK - szlak kinazy białkowej aktywowanej mitogenami, NF-kB - jądrowy czynnik transkrypcyjny NF kappa B, PI-4P - 4-fosforan fosfatydylo-mio-inozytolu, S1P - sfingozyno-1-fosforan, SPL - liaza sfingozyno-1-fosforanu STX17 - syntaksyna 17, UDP-glukoza - glukozodifosforan urydyny.

\section{Konflikt interesów}

Autorki deklarują brak potencjalnych konfliktów interesów.

\section{Piśmiennictwo}

[1] Cazalet C., Rusniok C., Brüggemann H., Zidane N., Magnier A., Ma L., Tichit M., Jarraud S., Bouchier C., Vandenesch F., Kunst F., Etienne J., Glaser P., Buchrieser C.: Evidence in the Legionella pneumophila genome for exploitation of host cell functions and high genome plasticity. Nat. Genet., 2004; 36:1165-1173

[2] Rolando M., Sanulli S., Rusniok C., Gomez-Valero L., Bertholet C., Sahr T., Margueron R., Buchrieser C.: Legionella pneumophila effector RomA uniquely modifies host chromatin to repress gene expression and promote intracellular bacterial replication. Cell Host Microbe, 2013; 13: 395-405

[3] Nisar M.A., Ross K.E., Brown M.H., Bentham R., Whiley H.: Legionella pneumophila and protozoan hosts: Implications for the control of hospital and potable water systems. Pathogens, 2020; 9: 286

[4] Palazzolo C., Maffongelli G., D’Abramo A., Lepore L., Mariano A., Vulcano A., Bartoli T.A., Bevilacqua N., Giancola M.L., Di Rosa E., Nicastri E.: Legionella pneumonia: Increased risk after COVID-19 lockdown? Italy, May to June 2020. Euro. Surveill., 2020; 25: 2001372

[5] Finnerty W.R., Makula R.A., Feeley J.C.: Cellular lipids of the Legionnaires' disease bacterium. Ann. Intern. Med., 1979; 90: 631634

[6] Vincent C.D., Friedman J.R., Jeong K.C., Buford E.C., Miller J.L., Vogel J.P.: Identification of the core transmembrane complex of the Legionella Dot/lcm type IV secretion system. Mol. Microbiol., 2006; 62: 1278-1291

[7] Palusińska-Szysz M., Russa R.: Chemical structure and biological significance of lipopolysaccharide from Legionella. Recent Pat. Antiinfect. Drug Discov., 2009; 4: 96-107

[8] Shevchuk O., Jäger J., Steinert M.: Virulence properties of the Legionella pneumophila cell envelope. Front. Microbiol., 2011; 2: 74

[9] Locht C., Coutte L., Mielcarek N.: The ins and outs of pertussis toxin. FEBS J., 2011; 278: 4668-4682

[10] Schmölders J., Manske C., Otto A., Hoffmann C., Steiner B., Welin A., Becher D., Hilbi H.: Comparative proteomics of purified pathogen vacuoles correlates intracellular replication of Legionella pneumophila with the small GTPase Ras-related protein 1 (Rap1). Mol. Cell. Proteomics, 2017; 16: 622-641

[11] Isberg R.R., O'Connor T.J., Heidtman M.: The Legionella pneumophila replication vacuole: Making a cosy niche inside host cells. Nat. Rev. Microbiol., 2009; 7: 13-24

[12] de la Cruz F., Frost L.S., Meyer R.J., Zechner E.L.: Conjugative DNA metabolism in gram-negative bacteria. FEMS Microbiol. Rev., 2010; 34: 18-40

[13] Newton H.J., Ang D.K., van Driel I.R., Hartland E.L.: Molecular pathogenesis of infections caused by Legionella pneumophila. Clin. Microbiol. Rev., 2010; 23: 274-298

[14] Palusińska-Szysz M., Cendrowska-Pinkosz M.: Występowanie i chorobotwórczość bakterii z rodziny Legionellaceae. Postępy Hig. Med. Dośw., 2008; 62: 337-353 
[15] Paumet F., Wesolowski J., Garcia-Diaz A., Delevoye C., Aulner N., Shuman H.A., Subtil A., Rothman J.E.: Intracellular bacteria encode inhibitory SNARE-like proteins. PLoS One, 2009; 4: e7375

[16] Chandran Darbari V., Waksman G.: Structural biology of bacterial type IV secretion systems. Annu. Rev. Biochem., 2015; 84: 603629

[17] Inaba J.I., Xu K., Kovalev N., Ramanathan H., Roy C.R., Lindenbach B.D., Nagy P.D.: Screening Legionella effectors for antiviral effects reveals Rab1 GTPase as a proviral factor coopted for tombusvirus replication. Proc. Natl. Acad. Sci. USA, 2019; 116: 21739-21747

[18] Segal G., Purcell M., Shuman H.A.: Host cell killing and bacterial conjugation require overlapping sets of genes within a $22-\mathrm{kb}$ region of the Legionella pneumophila genome. Proc. Natl. Acad. Sci. USA, 1998; 95: 1669-1674

[19] Zuckman D.M., Hung J.B., Roy C.R.: Pore-forming activity is not sufficient for Legionella pneumophila phagosome trafficking and intracellular growth. Mol. Microbiol., 1999; 32: 990-1001

[20] Sutherland M.C., Nguyen T.L., Tseng V., Vogel J.P.: The Legionella IcmSW complex directly interacts with DotL to mediate translocation of adaptor-dependent substrates. PLoS Path., 2012; 8: e1002910

[21] Nakano N., Kubori T., Kinoshita M., Imada K., Nagai H.: Crystal structure of Legionella DotD: Insights into the relationship between type IVB and type II/III secretion systems. PLoS Pathog., 2010; 6: e1001129

[22] Kirby J.E., Vogel J.P., Andrews H.L., Isberg R.R.: Evidence for pore-forming ability by Legionella pneumophila. Mol. Microbiol., 1998; 27: 323-336

[23] Durie C.L., Sheedlo M.J., Chung J.M., Byrne B.G., Su M., Knight T., Swanson M., Lacy D.B., Ohi M.D.: Structural analysis of the Legionella pneumophila Dot/lcm type IV secretion system core complex. eLife, 2020; 9: e59530

[24] Luo Z.Q., Isberg R.R.: Multiple substrates of the Legionella pneumophila Dot/lcm system identified by interbacterial protein transfer. Proc. Natl. Acad. Sci. USA, 2004; 101: 841-846

[25] Dorer M.S., Kirton D., Bader J.S., Isberg R.R.: RNA interference analysis of Legionella in Drosophila cells: Exploitation of early secretory apparatus dynamics. PLoS Pathog., 2006; 2: e34

[26] Kubori T., Koike M., Bui X.T., Higaki S., Aizawa S.I., Nagai H.: Native structure of a type IV secretion system core complex essential for Legionella pathogenesis. Proc. Natl. Acad. Sci. USA, 2014; 111: 11804-11809

[27] Meir A., Macé K., Lukoyanova N., Chetrit D., Hospenthal M.K., Redzej A., Roy C., Waksman G.: Mechanism of effector capture and delivery by the type IV secretion system from Legionella pneumophila. Nat. Commun., 2020; 11: 2864

[28] Vincent C.D., Friedman J.R., Jeong K.C., Sutherland M.C., Vogel J.P.: Identification of the DotL coupling protein subcomplex of the Legionella Dot/lcm type IV secretion system. Mol. Microbiol., 2012; 85: 378-391
[29] Kwak M.J., Kim J.D., Kim H., Kim C., Bowman J.W., Kim S., Joo K., Lee J., Jin K.S., Kim Y.G., Lee N.K., Jung J.U., Oh B.H.: Architecture of the type IV coupling protein complex of Legionella pneumophila. Nat. Microbiol., 2017; 2: 17114

[30] Massey T.H., Mercogliano C.P., Yates J., Sherratt D.J., Löwe J.: Double-stranded DNA translocation: Structure and mechanism of hexameric FtsK. Mol. Cell, 2006; 23: 457-469

[31] Morozova I., Qu X., Shi S., Asamani G., Greenberg J.E., Shuman H.A., Russo J.J.: Comparative sequence analysis of the $\mathrm{icm} / \mathrm{dot}$ genes in Legionella. Plasmid, 2004; 51: 127-147

[32] Szpirer C.Y., Faelen M., Couturier M.: Interaction between the RP4 coupling protein TraG and the pBHR1 mobilization protein Mob. Mol. Microbiol., 2000; 37: 1283-1292

[33] Tato I., Zunzunegui S., de la Cruz F., Cabezon E.: TrwB, the coupling protein involved in DNA transport during bacterial conjugation, is a DNA-dependent ATPase. Proc. Natl. Acad. Sci. USA, 2005; 102: 8156-8161

[34] Sexton J.A., Miller J.L., Yoneda A., Kehl-Fie T.E., Vogel J.P.: Legionella pneumophila DotU and IcmF are required for stability of the Dot/lcm complex. Infect. Immun., 2004; 72: 5983-5992

[35] Kim H., Kubori T., Yamazaki K., Kwak M.J., Park S.Y., Nagai H., Vogel J.P., Oh B.H.: Structural basis for effector protein recognition by the Dot/lcm Type IVB coupling protein complex. Nat. Commun., 2020; 11: 2623

[36] Parsot C., Hamiaux C., Page A.L.: The various and varying roles of specific chaperones in type III secretion systems. Curr. Opin. Microbiol., 2003; 6: 7-14

[37] Ninio S., Zuckman-Cholon D.M., Cambronne E.D., Roy C.R.: The Legionella IcmS-IcmW protein complex is important for Dot/lcmmediated protein translocation. Mol. Microbiol., 2005; 55: 912-926

[38] Nagai H., Cambronne E.D., Kagan J.C., Amor J.C., Kahn R.A., Roy C.R.: A C-terminal translocation signal required for Dot/lcmdependent delivery of the Legionella RalF protein to host cells. Proc. Natl. Acad. Sci. USA, 2005; 102: 826-831

[39] Huang L., Boyd D., Amyot W.M., Hempstead A.D., Luo Z.Q., O'Connor T.J., Chen C., Machner M., Montminy T., Isberg R.R.: The E Block motif is associated with Legionella pneumophila translocated substrates. Cell. Microbiol., 2011; 13: 227-245

[40] Matthews M., Roy C.R.: Identification and subcellular localization of the Legionella pneumophila IcmX protein: A factor essential for establishment of a replicative organelle in eukaryotic host cells. Infect. Immun., 2000; 68: 3971-3982

[41] Schuelein R., Spencer H., Dagley L.F., Li P.F., Luo L., Stow J.L., Abraham G., Naderer T., Gomez-Valero L., Buchrieser C., Sugimoto C., Yamagishi J., Webb A.I., Pasricha S., Hartland E.L.: Targeting of RNA polymerase II by a nuclear Legionella pneumophila Dot/lcm effector SnpL. Cell. Microbiol., 2018; 20: e12852

[42] Farelli J.D., Gumbart J.C., Akey I.V., Hempstead A., Amyot W., Head J.F., McKnight C.J., Isberg R.R., Akey C.W.: IcmQ in the type $4 \mathrm{~b}$ secretion system contains an $\mathrm{NAD}^{+}$binding domain. Structure, 2013; 21: 1361-1373 
[43] Jørgensen R., Wang Y., Visschedyk D., Merrill A.R.: The nature and character of the transition state for the ADP-ribosyltransferase reaction. EMBO Rep., 2008; 9: 802-809

[44] Quaile A.T., Stogios P.J., Egorova O., Evdokimova E., Valleau D., Nocek B., Kompella P.S., Peisajovich S., Yakunin A.F., Ensminger A.W., Savchenko A.: The Legionella pneumophila effector Ceg4 is a phosphotyrosine phosphatase that attenuates activation of eukaryotic MAPK pathways. J. Biol. Chem., 2018; 293: 3307-3320

[45] Sexton J.A., Yeo H.J., Vogel J.P.: Genetic analysis of the Legionella pneumophila DotB ATPase reveals a role in type IV secretion system protein export. Mol. Microbiol., 2005: 57, 70-84

[46] Sherwood R.K., Roy C.R.: Autophagy evasion and endoplasmic reticulum subversion: The yin and yang of Legionella intracellular infection. Annu. Rev. Microbiol., 2016; 70: 413-433

[47] Laguna R.K., Creasey E.A., Li Z., Valtz N., Isberg R.R.: A Legionella pneumophila translocated substrate that is required for growth within macrophages and protection from host cell death. Proc. Natl. Acad. Sci. USA, 2006; 103: 18745-18750

[48] Quan F.S., Kong H.H., Lee H.A., Chu K.B., Moona E.K.: Identification of differentially expressed Legionella genes during its intracellular growth in Acanthamoeba. Heliyon., 2020; 6: e05238

[49] Park D., Chetrit D., Hu B., Roy C.R., Liu J.: Analysis of Dot/lcm type IVB secretion system subassemblies by cryoelectron tomography reveals conformational changes induced by DotB binding. mBio, 2020; 11: e03328-19

[50] Nagai H., Kubori T.: Type IVB Secretion systems of Legionella and other Gram-negative bacteria. Front. Microbiol., 2011; 2: 136

[51] Kuroda T., Kubori T., Bui X.T., Hyakutake A., Uchida Y, Imad K., Nagai H.: Molecular and structural analysis of Legionella Dotl gives insights into an inner membrane complex essential for type IV secretion. Sci. Rep., 2015; 5: 10912

[52] Kubori T., Nagai H.: The Type IVB secretion system: An enigmatic chimera. Curr. Opin. Microbiol., 2016; 29: 22-29

[53] Roy C.R., Isberg R.R.: Topology of Legionella pneumophila DotA: An inner membrane protein required for replication in macrophages. Infect. Immun., 1997; 65: 571-578

[54] Higgins C.F.: The ABC of channel regulation. Cell, 1995; 82: 693696

[55] Hsu F.S., Zhu W., Brennan L., Tao L., Luo Z.Q., Mao Y.: Structural basis for substrate recognition by a unique Legionella phosphoinositide phosphatase. Proc. Natl. Acad. Sci. USA, 2012; 1090: 13567-13572

[56] Vance J.E., Vance D.E.: Phospholipid biosynthesis in mammalian cells. Biochem. Cell Biol., 2004; 82: 113-128

[57] Gal-Mor O., Zusman T., Segal G.: Analysis of DNA regulatory elements required for expression of the Legionella pneumophila icm and dot virulence genes. J. Bacteriol., 2002; 184: 3823-3833

[58] Ramsey M.E., Woodhams K.L., Dillard J.P.: The gonococcal genetic island and type IV secretion in the pathogenic Neisseria. Front. Microbiol., 2011; 2: 61
[59] Heidtman M., Chen E.J., Moy M.Y., Isberg R.R.: Large-scale identification of Legionella pneumophila Dot/lcm substrates that modulate host cell vesicle trafficking pathways. Cell. Microbiol., 2009; 11: 230-248

[60] Hirsch C., Gauss R., Horn S.C., Neuber O., Sommer T.: The ubiquitylation machinery of the endoplasmic reticulum. Nature, 2009; 458: 453-460

[61] Price C.T., Al-Khodor S., Al-Quadan T., Santic M., Habyarimana F., Kalia A., Kwaik Y.A.: Molecular mimicry by an F-box effector of Legionella pneumophila hijacks a conserved polyubiquitination machinery within macrophages and protozoa. PLoS Pathog., 2009; 5: e1000704

[62] Sampei G., Furuya N., Tachibana K., Saitou Y., Suzuki T., Mizobuchi K., Komano T.: Complete genome sequence of the incompatibility group I1 plasmid R64. Plasmid, 2010; 64: 92-103

[63] Rolando M., Escoll P., Nora T., Botti J., Boitez V., Bedia C., Daniels C., Abraham G., Stogios P.J., Skarina T. i wsp.: Legionella pneumophila S1P-lyase targets host sphingolipid metabolism and restrains autophagy. Proc. Natl. Acad. Sci. USA, 2016; 113: 19011906

[64] Nachmias N., Zusman T., Segal G.: Study of Legionella effector domains revealed novel and prevalent phosphatidylinositol 3-phosphate binding domains. Infect. Immun., 2019; 87: e0015319

[65] Grohmann E., Christie P.J., Waksman G., Backert S.: Type IV secretion in gram-negative and gram-positive bacteria. Mol. Microbiol., 2018; 107: 455-471

[66] Hoffmann C., Finsel I., Otto A., Pfaffinger G., Rothmeier E., Hecker M., Becher D., Hilbi H.: Functional analysis of novel Rab GTPases identified in the proteome of purified Legionella-containing vacuoles from macrophages. Cell. Microbiol., 2014; 16: 1034-1052

[67] Lightfield K.L., Persson J., Brubaker S.W., Witte C.E., von Moltke J., Dunipace E.A., Henry T., Sun Y.H., Cado D., Dietrich W.F., Monack D.M., Tsolis R.M., Vance R E.: Critical function for Naip5 in inflammasome activation by a conserved carboxy-terminal domain of flagellin. Nat. Immunol., 2008; 9: 1171-1178

[68] Rothmeier E., Pfaffinger G., Hoffmann C., Harrison C.F., Grabmayr H., Repnik U., Hannemann M., Wölke S., Bausch A., Griffiths G. i wsp.: Activation of Ran GTPase by a Legionella effector promotes microtubule polymerization, pathogen vacuole motility and infection. PLoS Pathog., 2013; 9: e1003598

[69] Shen X., Banga S., Liu Y., Xu L., Gao P., Shamovsky I., Nudler E., Luo Z.Q.: Targeting eEF1A by a Legionella pneumophila effector leads to inhibition of protein synthesis and induction of host stress response. Cell. Microbiol., 2009; 11: 911-926

[70] Derré I., Isberg R.R.: Legionella pneumophila replication vacuole formation involves rapid recruitment of proteins of the early secretory system. Infect. Immun., 2004; 72: 3048-3053

[71] Ingmundson A., Delprato A., Lambright D.G., Roy C.R.: Legionella pneumophila proteins that regulate Rab1 membrane cycling. Nature, 2007; 450: 365-369 
[72] Machner M.P., Isberg R.R.: A bifunctional bacterial protein links GDI displacement to Rab1 activation. Science, 2007; 318: 974977

[73] Shin S., Case C.L., Archer K.A., Nogueira C.V., Kobayashi K.S., Flavell R.A., Roy C.R., Zamboni D.S.: Type IV secretion-dependent activation of host MAP kinases induces an increased proinflammatory cytokine response to Legionella pneumophila. PLoS Pathog., 2008; 4: e1000220

[74] Pan X., Lührmann A., Satoh A., Laskowski-Arce M.A., Roy C.R.: Ankyrin repeat proteins comprise a diverse family of bacterial type IV effectors. Science, 2008; 320: 1651-1654

[75] Purcell M., Shuman H.A.: The Legionella pneumophila icmGCDJBF genes are required for killing of human macrophages. Infect. Immun., 1998; 66: 2245-2255

[76] Qiu J., Sheedlo M.J., Yu K., Tan Y., Nakayasu E.S., Das C., Liu X., Luo Z.Q.: Ubiquitination independent of $E 1$ and $E 2$ enzymes by bacterial effectors. Nature, 2016; 533: 120-124

[77] Steiner B., Swart A.L., Welin A., Weber S., Personnic N., Kaech A., Freyre C., Ziegler U., Klemm R.W., Hilbi H.: ER remodeling by the large GTPase atlastin promotes vacuolar growth of Legionella pneumophila. EMBO Rep., 2017; 18: 1817-1836

[78] Escoll P., Song O.R., Viana F., Steiner B., Lagache T., OlivoMarin J.C., Impens F., Brodin P., Hilbi H., Buchrieser C.: Legionella pneumophila modulates mitochondrial dynamics to trigger metabolic repurposing of infected macrophages. Cell. Host Microbe, 2017; 22: 302-316.e7

[79] Machner M.P., Isberg R.R.: Targeting of host Rab GTPase function by the intravacuolar pathogen Legionella pneumophila. Dev. Cell., 2006; 11: 47-56

[80] Amor J.C., Swails J., Zhu X., Roy C.R., Nagai H., Ingmundson A., Cheng X., Kahn R.A.: The structure of RalF, an ADP-ribosylation factor guanine nucleotide exchange factor from Legionella pneumophila, reveals the presence of a cap over the active site. J. Biol. Chem., 2005; 280: 1392-1400

[81] Meir A., Chetrit D., Liu L., Roy C.R., Waksman G.: Legionella DotM structure reveals a role in effector recruiting to the Type 4B secretion system. Nat. Commun., 2018; 9: 507

[82] Nagai H., Kagan J.C., Zhu X., Kahn R.A., Roy C.R.: A bacterial guanine nucleotide exchange factor activates ARF on Legionella phagosomes. Science, 2002; 295: 679-682

[83] Brombacher E., Urwyler S., Ragaz C., Weber S.S., Kami K., Overduin M., Hilbi H.: Rab1 guanine nucleotide exchange factor SidM is a major phosphatidylinositol 4-phosphate-binding effector protein of Legionella pneumophila. J. Biol. Chem., 2009; 284: 4846-4856

[84] Chen J., Reyes M., Clarke M., Shuman H.A.: Host cell-dependent secretion and translocation of the LepA and LepB effectors of Legionella pneumophila. Cell. Microbiol., 2007; 9: 1660-1671
[85] Conover G.M., Derré I., Vogel J.P., Isberg R.R.: The Legionella pneumophila LidA protein: A translocated substrate of the Dot/lcm system associated with maintenance of bacterial integrity. Mol. Microbiol., 2003; 48: 305-321

[86] Choy A., Dancourt J., Mugo B., O'Connor T.J., Isberg R.R., Melia T.J., Roy C.R.: The Legionella effector RavZ inhibits host autophagy through irreversible Atg8 deconjugation. Science, 2012; 338: 1072-1076

[87] Creasey E.A., Isberg R.R.: The protein SdhA maintains the integrity of the Legionella-containing vacuole. Proc. Natl. Acad. Sci. USA, 2012: 109: 3481-3486

[88] Banga S., Gao P., Shen X., Fiscus V., Zong W.X., Chen L., Luo Z.Q.: Legionella pneumophila inhibits macrophage apoptosis by targeting pro-death members of the Bcl2 protein family. Proc. Natl. Acad. Sci. USA, 2007; 104: 5121-5126

[89] Gan N., Nakayasu E.S., Hollenbeck P.J., Luo Z.Q.: Legionella pneumophila inhibits immune signalling via MavC-mediated transglutaminase-induced ubiquitination of UBE2N. Nat. Microbiol., 2019; 4: 134-143

[90] Losick V.P., Haenssler E., Moy M.Y., Isberg R.R.: LnaB: A Legionella pneumophila activator of NF-kB. Cell. Microbiol., 2010: 12: 1083-1097

[91] Ge J., Xu H., Li T., Zhou Y., Zhang Z., Li S., Liu L., Shao F.: A Legionella type IV effector activates the NF-KB pathway by phosphorylating the IkB family of inhibitors. Proc. Natl. Acad. Sci. USA, 2009; 106: 13725-13730

[92] Ivanov S.S., Roy C.R.: Modulation of ubiquitin dynamics and suppression of DALIS formation by the Legionella pneumophila Dot/ Icm system. Cell. Microbiol., 2009; 11: 261-278

[93] Fontana M.F., Banga S., Barry K.C., Shen X., Tan Y., Luo Z.Q., Vance R.E.: Secreted bacterial effectors that inhibit host protein synthesis are critical for induction of the innate immune response to virulent Legionella pneumophila. PLoS Pathog., 2011; 7: e1001289

[94] Joseph A.M., Pohl A., Ball T.J., Abram T.G., Johnson D.K., Geisbrecht B.V., Shames S.R.: The Legionella pneumophila metaeffector Lpg2505 (Mesl) regulates Sidl-mediated translation inhibition and novel glycosyl hydrolase activity. Infect. Immun., 2020; 88: e00853-19

[95] Belyi Y., Niggeweg R., Opitz B., Vogelsgesang M., Hippenstiel S., Wilm M., Aktories K.: Legionella pneumophila glucosyl transferase inhibits host elongation factor $1 \mathrm{~A}$. Proc. Natl. Acad. Sci. USA, 2006; 103: 16953-16958

[96] Silverman P.M., Clarke M.B.: New insights into F-pilus structure, dynamics, and function. Integr. Biol., 2010; 2: 25-31 